\title{
A comparative study on the utilisation of 3 cereals (barley, wheat, maize) in early weaned piglets
}

\author{
P. QUÉMÉRÉ (1), G. BERTRAND (1) et J. CHAUVEL ( $\left.{ }^{2}\right)$ \\ (') Institut Supérieur Agricole, 60026 Beauvais (France) \\ (2) Institut Technique du Porc, \\ I49, nue de Bercy, 75579 Paris Cedex I2
}

Four consecutive experiments, each one lasting from 28 to 39 days, were carried out with early weaned piglets in order to compare the feeding value of different " cereal-diets " (barley, wheat, maize) used separately or mixed.

Each trial involved 120 piglets set out in compartments of ten $(5 s, 5$ o ) on a flat deck.

The results gave the following indications :

$\rightarrow$ the intake of the wheat diets was not as favourable as that of the other ones, but the feed conversion ratio was better; the "barley-diets" presented a higher intake level, but a lower feed conversion ratio; the "maize-diets" were located between the two preceding ones.

According to the growth rates obtained there was no difference in the feeding value of the 3 cereals and moreover no replication of the data was possible.

Economic reasons are therefore determinant in the choice of cereals, since any substitution between high quality cereals seems to be possible.

\section{Waxy versus normal maize : Energy value for growing pigs and piglets}

\author{
J. M. PEREZ et A. AUMAITRE \\ Station de Recherches sur l'Elevage des Porcs, \\ I.N.R.A.C.N.R.Z., 78350 Jouy-en-Josas (France)
}

Three experiments were performed on growing pigs and piglets in order to determine the feeding value of amylopectin rich waxy maize.

A digestibility trial $(A)$ was realized on growing pigs (5 castrated Large White males per group) placed in balance cages with total collecting of excreta for ro consecutive days. The diets consisted exclusively of maize, either normal (group I) or waxy (group 2), only re-balanced with minerals, vitamins and essential amino acids. The results obtained showed a better utilization of the energy of waxy maize (group 2):

$\mathrm{ADE} 90.3$ versus $88.4(\mathrm{P}<0.05)$ digestible energy $3,980=28$ vs $3,914=\mathrm{I} 3(\mathrm{P}<0.10)$ apparent metabolisable energy: 3,887 vs $3,832\left(\mathrm{P}<0\right.$.10) or corrected $\mathrm{ME}_{n}: 3,839$ vs 3,787 $(\mathrm{P}<0 . \mathrm{Io}) \mathrm{Keal}$ per $\mathrm{kg}$ dry matter. The utilization of crude protein was slightly in favour of waxy maize: ADN 86.3 vs 85.6 (NS) retained nitrogen: 15.2 vs $14.2 \mathrm{~g} / \mathrm{d}(\mathrm{P}<0.10)$.

In trial $B$, utilization of two types of maize of the same variety and isogenic except for the waxy gene was studied in piglets weaned at 2 I days ( 24 animals per treatment). These two types of maize (the same as those tested in trial A), were introduced into isonitrogenous diets $(22.5 \% \mathrm{CP})$ at a level of 60 per cent. The performances obtained in the animals did not depend on the experimental diet (daily mean gain $366 \mathrm{~g}$, feed conversion ratio 1.62 between 3 and 9 weeks of age). This was also the case for the apparent digestibility of the main ingredients of the ration (DM, OM, N) measured by means of an indirect method using a chromium oxyde marker. However, a great variability in the responses was observed, notably between replications.

In trial $C$, the same type of comparison was made on a larger stock of animals (a total of $\mathrm{I} 28$ piglets weaned at 35 days). The normal maize (group I) or waxy maize (group 2 ) belonged 
to the same variety and were introduced at the level of 70 per cent into isonitrogenous diets ( $20 \% \mathrm{CP}$ ) offered till the age of 9 weeks. In these conditions, a marked effect was noticed in favour of waxy maize:

Daily mean gain: $470 \mathrm{~g}$ (group 2) versus $\mathbf{4 3 4} \mathrm{g}$ (group 1), i.e. a significant increase of 8 per cent $\left(\mathrm{P}<0.05\right.$ ); feed conversion ratio 1.76 (group 2) versus $\mathrm{I} .8_{4}$ (group $\left.\mathrm{I}\right)(\mathrm{P}<\mathrm{0.10}$ ).

Parallel to that an in vitro digestibility assay was made with the two types of maize of trial $C$. The results showed that the breakdown of waxy maize starch was more rapid in the presence of piglet pancreatic juice, a fact suggesting that the energy of this type of maize is more available.

\title{
Influence of diet on respiratory quotients and fat deposition in growing pigs
}

\author{
Geneviève CHARIET-LÉRY et Marie-Thérèse MOREL \\ Laboratoive de Physiologie de la Nutrition, \\ I.N.R.A.C.N.R.Z., 78350 Jouy-en-Josas (France)
}

\begin{abstract}
Short-lasting measurements of gascous exchanges in total confinement repeaterl several times during the day were used to study variations in these exchanges and in the respiratory quotient (RQ) during $23 \mathrm{~h}$ after meal eating in growing pigs $(3.5-65 \mathrm{~kg})$.

$R Q$ variations showed that lipogenesis took place during the first post eating hours, whatever the protein concentration of the diet, protein free normal or high protein level $(25 \%$ DM). In the latter conditions values inferior to $1(0,85)$ were observed when lipogenesis was occurring.

Fat deposition W.75 was highly correlated with ingested carbohydrates $/ W .75(r=-0.99$ $\mathrm{l}^{\prime}<\mathrm{o.oI}$ ), and energy efficiency of fat deposition (kf) was 0.76 . Any lowering of the carbohydrate supply compensated for by an increase in the protein supply slowed down the lipogenesis in growing pigs.
\end{abstract}

\section{Ad libitum or restricted feeding of female pigs receiving a maize soya-bean diet in the form of meal or pellet during the growing-finishing period}

\author{
J. CASTAING (1) et M. LEUILLET $\left({ }^{2}\right)$ \\ (1) Association générale des Producteurs de Maïs, \\ I, place de Lestapis, 6 fooo Pau (France) \\ (2) Institut Technique des Céréales et des Fourrages, \\ 8, avenue du Président-Wilson, 75116 Paris
}

Four feeding schedules were studied in female pigs derived from Large White $\times$ Jandrace dams and Latidrace sires. The diets were based on maize and offered either in the form of meal or pellets:

- feed resfiction during the whole growing period. The feed restriction plan was that usually applied in our previous trials. It was established according to the weight of the animals and involved a maximum supply of $80 \mathrm{~kg}$ feed $(2,8 \mathrm{~kg} / \mathrm{day} / \mathrm{animal})$. animal, :

_ad-libitum feeding until $60 \mathrm{~kg}$ live weight followed by a feeding plateau of $2,5.5 \mathrm{~kg} / \mathrm{day} /$

$\therefore$ ad libitum feeding until $60 \mathrm{~kg}$ live weight then a feeding plateau of $2.8 \mathrm{~kg} / \mathrm{day} / \mathrm{animal}$,

- ad libitum feeding until slaugiter.

Considering the overall experimental period, the daily mean intakes regularly increased from the most restricted treatment i to the ad libitum treatment 4 . The values obtained were 